\title{
2. The Finnish social security system: Background to the Finnish basic income experiment
}

\author{
Olli Kangas and Miska Simanainen
}

\section{INTRODUCTION}

All basic income experiments so far have been planned and implemented in national or local contexts. Thus, the questions posed in the experiments and the answers achieved are bound to time and place. To understand the motivations behind the experiments and the results achieved, we need familiarity with the institutional frameworks in which they occur. This also applies to the Finnish basic income experiment. In this chapter, we shed light on the context in which the experiment was planned, implemented, and carried out. The Finnish social protection system is comprehensive, and because of its comprehensiveness, it is complicated and difficult to describe in a simple way. We shall try anyway.

In its simplest form, the Finnish social security comprises three parts. The first part guarantees minimum income security for all Finnish residents (rather than citizens, as explained below). It includes 'basic level' social benefits paid either at a flat-rate or after means-testing based on personal or household income. The second part consists of income-related social insurance for those in employment. The third part of the system includes municipal social and health care services covering all residents from cradle to grave. (Kela, 2019).

In large part due to this comprehensiveness, the Finnish welfare state ranks top in the world in many aspects of economic and non-economic well-being. In Finland, shares of people at risk of poverty or social exclusion are among the lowest in the EU, for the total population and among all age groups. The income transfer system effectively lifts low-income people above the poverty line and equalises income differences (for example, Olafsson et al., 2019; Eurostat, 2020). Free or affordable public services just as effectively promote social inclusion through good quality education, health and social services, and public employment services, among many others. 
Needless to say, comprehensive social protection has its costs. Finland's gross social spending is near 30 percent of its gross domestic product (data for 2019), second only to France among OECD countries. Two thirds of total social spending goes to cash benefits and the remainder to providing social and health services (OECD, 2020b).

High spending demands high tax rates. Total tax revenues correspond to 42 percent of the GDP compared with the OECD average of 20 percent (as of 2018). The main sources of revenue are taxes on income and profits (15 percent of GDP), taxes on goods and services (14 percent), and social security contributions (12 percent) (OECD, 2020c). In Finland, both the central government and local municipalities collect taxes to finance their duties.

In its comprehensiveness, the Finnish social security system is also complicated. For mainly bureaucratic reasons, people can become trapped in it and there may be several disincentives to try to find employment or accept job offers. There have been multiple attempts to simplify the system, but results have been poor. Not surprisingly, barriers to employment (for example because of high effective marginal and participation tax rates) and measures aimed at increasing labour force participation have been the main areas of interest. In a sense, the Finnish basic income experiment was just one episode in a never-ending quest for getting the unemployed to work.

In the interest of simplicity and concision, this chapter focuses on those social policy schemes that produce the income and bureaucracy traps and disincentives, touched upon above. That is, the focus is on the interplay between the various income-tested benefits, such as housing allowances, and social assistance combined with progressive taxation. Furthermore, some cash-for-care schemes create their own disincentives, particularly for women. Since basic income - at least in the Finnish context and policy discourse - is not to alter social, education, or health care services, we discuss provision of public services only cursorily.

The structure or this chapter is as follows: first we provide a brief and simplified description of the functional logic of the Finnish social security system, followed by a section describing benefits that target children and families. Some of these benefits are universal, such as child allowance, and do not contribute to income traps. However, some family benefits are income tested or are compensations for at home care work, such as the cash-for-care child home care allowance. These have ramifications, including negative impacts on the labour market behaviour of individuals. Since unemployed persons were the target group of the Finnish basic income experiment, the third section focuses on the structure of unemployment benefits and on last resort social assistance. Oftentimes, those who receive basic unemployment benefits also receive housing allowances and social assistance, which is problematic from the perspective of work incentives, as will be shown. The penultimate section 
describes the income and bureaucratic traps in the current income transfer system, and the final section concludes the central lessons from the previous sections.

\section{THE DUAL STRUCTURE OF THE FINNISH INCOME TRANSFER SYSTEM}

The Finnish system deviates from many other welfare states in two important ways. First, the minimum benefits are intended to guarantee basic security and a decent livelihood for every Finnish resident regardless of employment history. These flat-rate or income-tested benefits are mainly paid by the Social Insurance Institution of Finland (Kela), which also pays out basic social assistance benefits. Municipalities are responsible for supplementary and preventive social assistance and some cash-for-care schemes (Figure 2.1).

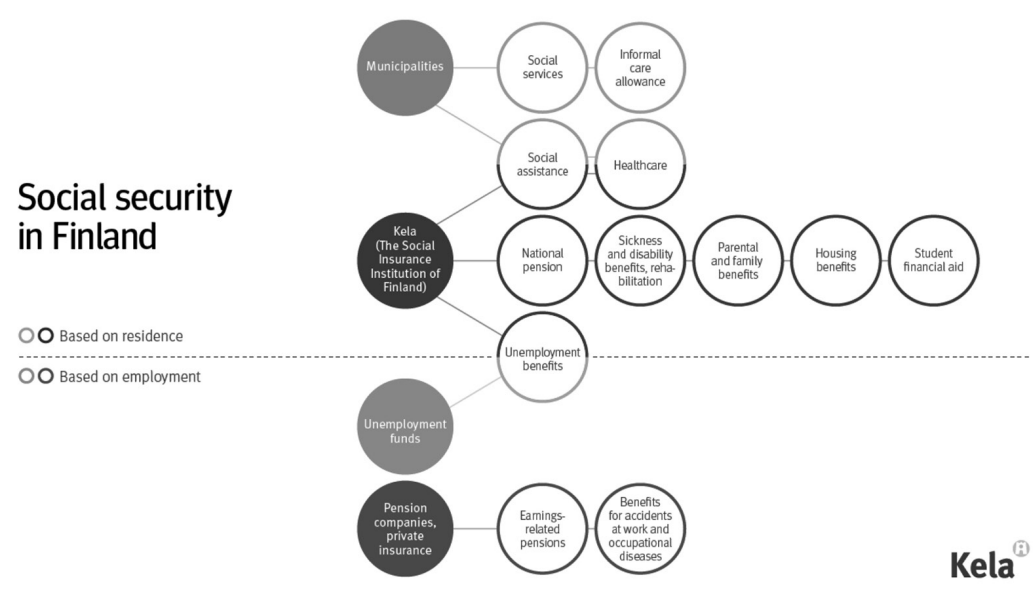

Figure 2.1 The division of labour between residence-based and employment-based income transfer schemes in Finland

As briefly noted above, entitlement to benefits is based on residency, rather than citizenship. The Constitution of Finland (731/1999) states:

Those who cannot obtain the means necessary for a life of dignity have the right to receive indispensable subsistence and care. Everyone shall be guaranteed by the Act the right to basic subsistence in the event of unemployment, illness, and disability, and during old age as well as at the birth of a child or the loss of a provider. The public authorities shall guarantee for everyone, as provided in more detail by the 
Act, adequate social, health, and medical services and promote the health of the population.

In that sense, some elements of basic income already exist in Finland.

Second, earnings-related benefits aim to guarantee the achieved consumption level if a claimant's income from employment ceases because of social risks such as illness, unemployment, disability, old age, and the like. The peculiarity of Finnish income transfer schemes is that there are no ceilings on benefits. Benefit amounts are wholly based on previous earnings. Furthermore, except for sickness insurance, all major forms of earnings-related social insurance are administered by either private insurance companies - as in the case of work accident insurance - or semi-private insurance institutions - as in the case of earnings-related pensions or voluntary unemployment funds providing earnings-related unemployment allowance. In the degree of corporatism in the administration of the social insurance system, Finland deviates from its Nordic neighbours.

Third, social security benefits and taxes and social security contributions are individual income based in Finland, as in the other Nordic countries (see Kautto, 2008; Kangas and Kvist, 2019), rather than household income based. Only in a very few schemes, such as housing allowance and social assistance transfers, is household income used as the basis for income-testing.

\section{BENEFITS FOR CHILDREN AND FAMILIES WITH CHILDREN}

Parents are entitled to the maternity or paternity allowance and the parental allowance for approximately four, two, and six months, respectively. The gross replacement rate is approximately 70 percent of income at the average income level. There is a minimum daily allowance (€724 per month as in 2020) available for parents with no or very low income.

The main child-related cash transfer is the child allowance, which is paid universally for every child below 16 years of age. The benefit amount is based on the number of children, and single parents receive higher benefits for each child.

Finland's dual system of early childhood care includes both day care service and a home care allowance in the form of a cash-for-care payment. Day care is a subjective right and is guaranteed for every child until they begin preschool at the age of six. The fees for public day care depend on the number of children in the family, the household's income, and the hours of care needed. The service is heavily subsidised and the fee ranges from $€ 0$ to $€ 300$ per month, per child (2020 data). 
Kela pays out the widely used cash-for-care home care allowance for children under three years old who are not enrolled in municipal day care. The basic amount (€340 per month) is available for all regardless of family income. Low-income families can receive Kela's care supplement (about $€ 180$ per month). Some municipalities, mainly bigger towns, pay additional supplements. For example, the capital Helsinki paid about $€ 250$ extra per month for child home care in 2020. Thus, in Helsinki the home care subsidy in low-income families totalled to $€ 770$ per month.

Home care allowances and additional benefits paid by municipalities are incentives for mothers to stay at home and utilise the possibilities to stay at home given by the home care allowance (Kosonen and Huttunen, 2018). Almost all parents use the home care allowance, although use is gender biased and approximately 80 percent of the benefit periods are used by the mother. While the use of the care allowance is not linked to users' socio-economic characteristics, the duration of use is linked to parents' educational and family status. Mothers with higher educational attainment tend to collect the care allowance for shorter time periods than mothers with lower educational attainment. Furthermore, single mothers use it for longer periods than mothers with spouses (Haataja and Juutilainen, 2014; Räsänen et al., 2019).

In addition to family benefits, roughly 15 percent of Finnish households, receive a Kela-administered general housing allowance, another important income transfer for low-income families with or without children (Kela, 2020a). The allowance aims to decrease housing costs and secure adequate housing for low-income households. 70 percent of all the costs of housing allowance goes to single-person households, two-parent families with children and childless couples receive about 7 percent each, and single parents 16 percent of all the costs (Findikaattori, 2020).

Housing allowances compensate families for 80 percent of their qualifying housing costs, as determined by the number of household members and their municipality of residence. The gross income of the household members affects the amount of the housing allowance. Income exceeding the amount of the basic unemployment benefit tapers the amount of the housing allowance, and an earnings deduction of $€ 300$ made from every household member's salary or self-employment income brings the tapering rate to 33.6 percent, i.e., earnings of $€ 100$ decreases the allowance by around $€ 34$.

\section{THE STRUCTURE OF THE FINNISH UNEMPLOYMENT PROTECTION SYSTEM}

The duality of Finnish social security is also reflected in the unemployment protection system, which includes both 'basic' and income-related benefits, as shown in Figure 2.2. 
There are two forms of basic unemployment income transfers, the basic allowance and the labour market subsidy, both of which are administered by Kela. They deliver the same gross monthly benefit amount ( $€ 734$ in 2020) but differ in their eligibility criteria. Whereas the labour market subsidy is a means-tested benefit for those with little or no employment history, the basic allowance targets applicants who have employment records but are not members in voluntary unemployment funds (a requirement for receiving the income-related unemployment allowance). The gross income-loss compensation level in the earnings-related scheme is about 60 percent at the average income level of $€ 3300$ per month.

\section{Employment condition satisfied}

Member of unemployment fund
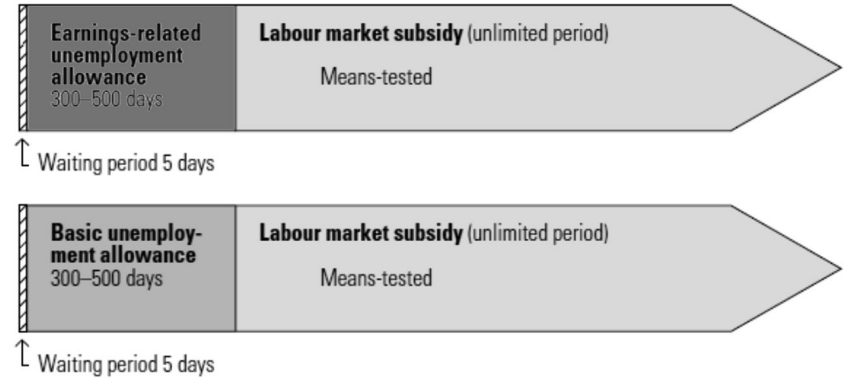

Employment condition not satisfied

Graduates with vocational qualifications
Labour market subsidy (unlimited period) Means-tested

$\uparrow$ Waiting period 5 days

Source: Kela, 2019: 385.

Figure 2.2 The structure of the Finnish unemployment benefit system

In principle, all three forms of unemployment benefits are conditional. Recipients must be registered as unemployed jobseekers in the Employment and Economic Development Office, must permanently reside in Finland, be 17 to 64 years old, be fit to work, and be available for full-time work (Kela, 2020b). The basic unemployment allowance and the income-related benefit are payable for from 300 to 500 weekdays depending on the age and work history of the claimant (for a more detailed description, see Kela, 2020b).

All three benefits are paid after a five-day waiting period. There are specific regulations for those younger than 25 who have not completed their vocational education, including a five-month qualifying period prior to eligibility 
for labour market subsidy, and a requirement to seek education. During the five-month period, they are entitled to social assistance.

As shown in Figure 2.2, if unemployment continues longer than the maximum periods for the basic allowance or income-related benefits, the unemployed person qualifies for the labour market subsidy that has an unlimited duration. The labour market subsidy is an income-tested benefit. One's own income may reduce the amount of the subsidy (but not the spouse's income). If the unemployed person lives with his or her parents, the parent's income may also reduce the amount of the subsidy. Social benefits such as child and housing allowances and income support are exempted from income-testing, and income-testing is not applied when the unemployed person participates in employment promotion measures (Kela, 2019).

There is an adjustment system for income from part-time or incidental work. With 'adjusted unemployment benefits' [soviteltu päiväraha] work income up to $€ 300$ per month (the 'exempt amount') does not reduce benefits, but income greater than the exempt amount reduces the benefit by certain tapering percentages, usually 50 percent.

\section{SOCIAL ASSISTANCE}

Social assistance in Finland is classified as last-resort financial assistance. It comprises three parts: basic social assistance, supplementary social assistance, and preventive social assistance. Basic social assistance is paid by Kela to clients who fulfil the formal low-income criteria (Figure 2.1). Supplementary social assistance is administered by municipalities and, after stricter needs-testing, is paid to compensate for additional and unanticipated costs, such as broken washing-machines or expensive medication. Preventive assistance, also administered by the municipalities, is paid after more careful means and needs-testing to help the claimants cope with difficult life situations. Preventive assistance is case sensitive and depends on municipal decisions. Neither of the three forms of social assistance are time-limited. They are paid as long as eligibility conditions are met.

In principle, social assistance is means-tested and conditional. Recipients must be available for work and willing to accept job offers. If the claimant does not comply with the requirements, benefits can be cut by up to 40 percent for a maximum of two months. The sanctions applied in Finland are the most lenient among European countries (Eleveld, 2016; Penttilä and Hiilamo, 2017).

The problem with the Finnish basic benefits (for example the basic unemployment allowance or the labour market subsidy) is that their level is so low that in most cases persons living on these benefits are entitled to social assistance. If a household has low income and problems paying its housing costs, social assistance may cover the shortfall. In fact, social assistance is an important part of supporting housing among low-income households. About half of all the costs 
of basic social assistance go toward compensations for housing costs (Jauhiainen, 2019; Jauhiainen and Korpela, 2019). Hence, social assistance is supplementary and simultaneous to a number of other basic security transfers and is paid on top of the other benefits. When the decision on the Finnish basic income experiment was made, more than 90 percent of households receiving social assistance also received some other Kela-administered basic benefits (Kela, 2015).

Income- and means-tested programmes tend to create work disincentives. For example, the tapering rate in social assistance is 100 percent. The most severe disincentive problems are in cases where the income basket consists of multiple income-tested transfers. Then, effective participation tax rates will be high, creating disincentives for the unemployed to accept job offers. These problems are more fully described below.

\section{INCOME TRAPS AND BUREAUCRATIC PROBLEMS}

The combination of the home care allowance, the housing allowance, and social assistance is problematic for labour force participation rates. It generates high effective marginal tax rates, creating severe income traps for recipients in general and for single parents in particular. Compared with other Nordic countries, labour force participation rates of mothers with small children are low in Finland. Whereas the employment rate of mothers whose youngest child is 0 to 2 years of age is approximately 50 percent in Finland, it is approximately 80 percent in neighbouring Sweden. In contrast to the comparatively low employment rates among mothers with small children, the employment rate of mothers with older children ( 6 to 14 years of age) is approximately 90 percent, among the highest in the OECD (OECD, 2020a).

Progressive income tax, in turn, contributes to high participation tax rates, that is, the fraction of additional gross earnings lost to higher taxes or lowered benefits upon employment. According to the OECD's tax-benefit (OECD, 2020d) calculations, participation tax rates for unemployed people in Finland vary from 68 percent for single unemployed people without children to 79 percent for single parents with two children.

Figure 2.3 describes income formation in two typical cases of unemployment. The upper panel illustrates what happens to a single person when employment and income from work increases from zero to $€ 2000$ per month. In the lower panel, a corresponding situation is depicted for a single parent with one child. The horizontal axis represents wages obtained from employment, and the vertical axis shows changes in social benefits and the development of disposable income after taxes.

As the upper graph indicates, if a single person is unemployed (wage $=0$ in the horizontal axis), his or her disposable income is about $€ 1100$ per month. Due to the adjusted labour market subsidy exempting work income up to $€ 300$ per month, 
work income up to that limit increases disposable income; thereafter, work income up to $€ 500$ per month does not increase disposable income at all, i.e., in this group the effective marginal tax rate is 100 percent. In the wage-income bracket of $€ 600$ to $€ 2000$, disposable income increases but only modestly.
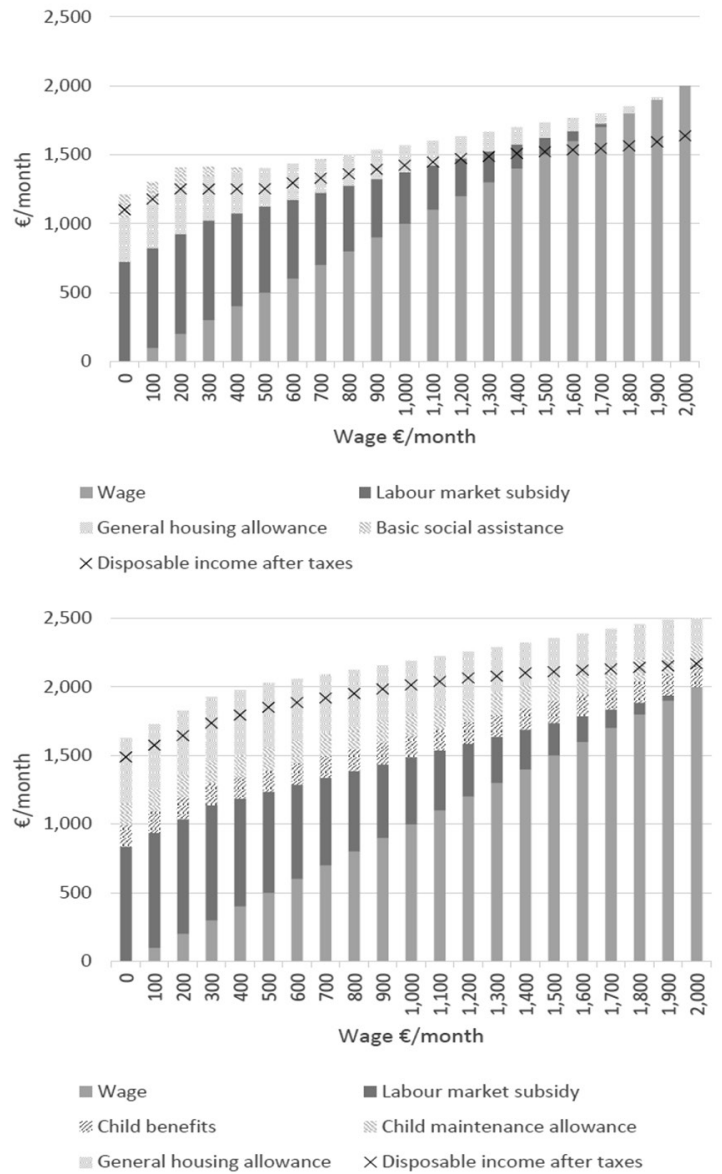

Note: The unemployed gets adjusted labour market subsidy, rent is $€ 600$ per month and lives in municipal category 3. Most of Finnish municipalities belong to that category. The rents housing allowance compensates depend on the municipality.

Figure 2.3 Composition of income formation of an unemployed person living alone and an unemployed single parent ${ }^{l}$ 
The lower part of the figure depicts the corresponding situation for a single parent. In this case, the disposable income while unemployed is about $€ 1500$ per month. If work income increases from $€ 0$ to $€ 1000$ per month, disposable income increases by $€ 500$, whereas a wage increase from $€ 1000$ to $€ 2000$ adds about $€ 200$ to the disposable income. Increases in the disposable income are smaller when possible child day care fees are included in the simulations.

High tax rates and net income that increases too slowly after receiving employment are one aspect of the incentive problem. If work does not pay or does not pay enough, unemployed people may choose to stay at home instead of obtaining employment. Additionally, eliminating the various bureaucratic traps that make unemployed people cautious about accepting short-term work offers has yet to be achieved. Owing to complicated eligibility criteria, and waiting periods during benefit handling processes, recipients may be averse to accepting job offers in general and offers for temporary and part-time jobs in particular.

\section{CONCLUSIONS: THE (IM)POSSIBILITY OF ABOLISHING INCENTIVE TRAPS}

The most common question we have answered since starting to plan the Finnish basic income experiment is, why did Finland implement a basic income experiment? Questioners to some extent familiar with the Finnish social security system have wondered, why not simply take the final step and implement universal basic income when there already seem to be elements of basic income in the Finnish income transfer system?

Indeed, in a sense Finland is already a basic income country. We have a universal income transfer scheme for all children younger than 17 years of age combined with free school meals and free school health care. All students have free study grants and free education, and basic pensions are paid to all elderly people who have not accrued an earnings-related pension or their pension is too low. Furthermore, labour market subsidies and social assistance have some resemblance to partial basic income. Benefits can be received indefinitely, and although benefits are conditional the sanctions (if they are applied) are among the most lenient in the European hemisphere. Thus, why not implement basic income? Why was an experiment needed?

As described above, the combination of taxes and means-tested benefits that are paid on top of each other too often lead to situations where income from employment increases disposable income very little or, in some cases, not at all. Sometimes, the net result can be even negative. During the three decades, consecutive governments of varying political compositions have attempted to solve these incentive problems, but without greater success. 
The policy dilemma seems to be a mission impossible. In 2015, the Centre-Right government of Prime Minister Juha Sipilä wrote in its Governmental programme, quite out of the blue, that the government wanted to study whether basic income would solve the wicked (and for politicians also embarrassing) problem of persistently high unemployment and whether basic income would be an effective policy device to combat monetary and bureaucratic disincentives in the current Finnish income transfer system. Subsequent chapters in this volume give answers to that question.

\section{NOTE}

1. The unemployed has one child, gets adjusted labour market subsidy, the rent is $€ 600$ per month, and lives in municipal category 3. Day care fees are not included in the calculations. Source: SISU microsimulation model, Statistics Finland, the tax-benefit rules and parameters pertain to the year 2020 .

\section{REFERENCES}

Constitution of Finland (731/1999), Unofficial translation in English available at https:// finlex.fi/fi/laki/kaannokset/1999/en19990731.pdf) (retrieved 1 December 2020).

Eleveld, A. (2016), Work-related Sanctions in European Welfare States: An Incentive to Work or a Violation of Minimum Subsistence Rights? Amsterdam: The Amsterdam Centre for Contemporary European Studies, SSRN, Research Paper, 01.

Eurostat (2020), 'Income poverty statistics', Luxembourg: Eurostat, available at https:// ec.europa.eu/eurostat/statisticsexplained/index.php?title=Income poverty statistics \&oldid=440992\#At-risk-of-poverty_rate_and_threshold (retrieved 8 December 2020).

Findikaattori (2020), 'General housing allowance: Recipient households', available at https://findikaattori.fi/en/table/110 (retrieved 20 December 2020).

Haataja, A. and Juutilainen, V. P. (2014), 'Kuinka pitkään lasten kotihoitoa? Selvitys äitien lastenhoitojaksoista kotona 2000-luvulla' ['How long child home care? A study of mothers' child home care spells in the 2000s']. Helsinki: Kela, Working Paper 58 .

Jauhiainen, S. (2019), 'Toimeentulotuki ja asumisen kustannukset' [Social assistance and housing costs]. Presentation at Kela, 17 April 2019.

Jauhiainen, S. and Korpela, T. (2019), Toimeentulotuen saajien elämäntilanne, asuminen ja työnteko [Circumstances, Housing and Employment of Social Assistance Recipients], Helsinki: Valtioneuvoston selvitys-ja tutkimussarja 2019, 28.

Kangas, O. and Kvist, J. (2019), 'Nordic welfare states', in Greve, B. (ed.), Routledge Handbook of the Welfare State, London: Routledge, pp. 124-36.

Kautto, M. (2008), 'The Nordic countries', in Castles, F., Leibfried, S., Lewis, J., Obinger, H. and Pierson, C. (eds.), The Oxford Handbook of the Welfare State, Oxford: Oxford University Press, pp. 586-600.

Kela (2015), The Second Expert Group for Evaluation of the Adequacy of Basic Social Security: Adequacy of Basic Social Security in Finland, Helsinki: Kela, Working Papers 80/2015, pp. 2011-15. 
Kela (2019), Statistical Year Book 2018 of the Social Insurance Institution of Finland, Helsinki: Kela.

Kela (2020a), Kelan asumistukitilasto 2019 [Kela Statistics on Housing Allowance 2019], Helsinki: Kela.

Kela (2020b), 'Unemployment', Helsinki: Kela, available at https:/www.kela.fi/web/ en/unemployment (retrieved 7 December 2020).

Kosonen, T. and Huttunen, K. (2018), Kotihoidontuen vaikutus lapsiin [The Impact of Home Care Allowance on Children], Helsinki: Palkansaajien tutkimuslaitos ja VATT, Tutkimuksia 115/2018.

OECD (2020a), 'OECD Family data-base: Maternal employment rates', available at http://www.oecd.org/els/family/LMF1_2_Maternal_Employment.pdf (retrieved 6 December 2020).

OECD (2020b), Social Expenditure - Aggregated Data, Paris: OECD, available at https://stats.oecd.org/Index.aspx?DataSetCode=SOCX_AGG (retrieved 8 December 2020).

OECD (2020c), Tax Administration, Paris: OECD, available at https://www.oecd.org/ tax/administration/ (retrieved 8 December 2020).

OECD (2020d), The OECD Tax-Benefit Data Portal, Paris: OECD, available at http:// www.oecd.org/social/benefits-and-wages/data/ (retrieved 6 December 2020).

Olafsson S., Daly M., Kangas, O. and Palme, J. (eds.) (2019), Welfare and the Great Recession: A Comparative Study, Oxford: Oxford University Press.

Penttilä, R. and Hiilamo, H. (2017), 'Toimeentulotuen saajien sanktiointi eurooppalaisessa vertailussa' ['Sanctions in European minimum income schemes'], Yhteiskuntapolitiikka 82 (3), 404-16.

Räsänen, T., Österbacka, E., Valaste, M. and Haataja, A. (2019), Lastenhoidon tukien vaikutus äitien osallistumiseen työmarkkinoille [The Effect of Child Care Subsidies on Mothers' Labour Market Participation], Helsinki: Kela, Sosiaali-ja terveysturvan raportteja 14. 